TECHNICAL NOTES AND MANUALS

Revenue Administration: Performance Measurement in Tax Administration

William Crandall

Fiscal Affairs Department

INTER NA TI O N AL MONETARY FUND 


\section{INTERNATIONAL MONETARY FUND}

Fiscal Affairs Department

Revenue Administration:

Performance Measurement in Tax Administration

Prepared by William Crandall

Authorized for distribution by Carlo Cottarelli

June 2010

DISCLAIMER: This Technical Guidance Note should not be reported as representing the views

of the IMF. The views expressed in this Note are those of the authors and do not necessarily

represent those of the IMF or IMF policy.

\begin{tabular}{|l|l|}
\hline JEL Classification Numbers: & $\mathrm{H} 10, \mathrm{H} 11, \mathrm{H} 20, \mathrm{H} 24, \mathrm{H} 25$ \\
\hline Keywords: & $\begin{array}{l}\text { tax administration, performance measurement, performance management, } \\
\text { performance indicators, operational planning, strategic planning }\end{array}$ \\
\hline Author's E-Mail Address: & williamcrandall@canoemail.com \\
\hline
\end{tabular}




\title{
TECHNICAL NOTES AND MANUALS
}

\section{Revenue Administration: Performance Measurement in Tax Administration}

\author{
Prepared by William Crandall
}

This technical note addresses the following questions:

- What is performance management and performance measurement?

- How do tax administrations apply performance management at the strategic level?

- How do tax administrations apply performance management at the operational level?

- How do tax administrations apply performance management at the individual staff member level?

- What are some of the key tasks in implementing a performance management system?

- What has been the experience with performance management in different countries?

This note is about measuring performance in tax administration. Performance measurement is part of the broader processes of strategic and operational planning and is essential for accountability and transparency. With this in mind, there are two important considerations that form a backdrop for any discussion of performance measurement:

- First, measuring performance is only relevant if there are consequences for over and under-performance, and if organizational performance can influence such matters as the allocation of an organization's resources and the assessment of personal performance of its managers; and

- Second, as it is commonly argued that what gets measured gets done, performance measurement must be used to support the selection of the organization's priorities, so that what gets done is what should get done.

\section{What Is Performance Management and Performance Measurement?}

Performance measurement is an ongoing process of ascertaining how well, or how poorly, an organization is achieving its goals and objectives. ${ }^{1}$ It involves the continuous collection of

Note: William Crandall is a former Associate Deputy Minister of Revenue Canada and is a member of the IMF's Fiscal Affairs Department roster of experts. 
data on progress made in this regard. Performance indicators, or measures, are developed as standards for assessing the extent to which these objectives are achieved.

The terms performance measurement and performance management are often used interchangeably. However, performance management is a broader term that includes not only performance measurement but also the determination of the appropriate level of performance, the development and reporting of performance information, and the use of that information to assess the actual level of performance against the desired level. It refers to the process of looking after the objectives, approaches, institutional arrangements and performance information systems put in place to measure performance.

Performance measurement systems can provide several types of information, including information about inputs, activities, outputs and outcomes. These terms, and several other important ones are defined below:

- Inputs include resources dedicated to or consumed by the program. Examples are money, staff and staff time, facilities, equipment, and supplies. Inputs can also include constraints on the program, such as laws, regulations, and requirements for receipt of funding.

- Activities are what the program does with the inputs to fulfill its mission. Activities include the implementation of strategies, techniques, and types of treatment that comprise the program's service methodology.

- Outputs are the direct products of program activities and usually are measured in terms of the volume of work accomplished, for example, the numbers of audits conducted, appeals resolved, enforced collection actions, etc. Outputs have little inherent value in themselves. They are important because they are intended to lead to a desired result.

- Outcomes (or results) are benefits or changes for individuals or populations or government during or after completion of the program activities. They are influenced by a program's outputs. Outcomes may relate to behaviour and attitudes (compliance), equity and fairness (consistent treatment), or to revenues (financing for the state). Outcomes related to objectives are the medium-term changes that result from achieving the outputs. Outcomes related to goals are higher-level long term changes (these are sometimes referred to as impacts). ${ }^{2}$

- Performance indicators define the measurement of important and useful information about the performance of a program or activity expressed as a percentage,

\footnotetext{
${ }^{1}$ In this note, goals are high level outcomes which translate the general aims from the mission and vision statements into more concrete (and measurable) results. Objectives are more precise lower-level outcomes that give greater specificity to the goals.

${ }^{2}$ It is often easier to generate performance data on inputs and outputs than on outcomes and impacts. The relationship between inputs and outputs is relatively easy to measure, but measuring the relationship between inputs and outcomes is much more challenging. It is difficult to isolate the influence of the inputs from the many other factors that can affect the outcomes.
} 
index, rate or other comparison which is monitored at regular intervals and is compared to one or more criteria. Performance indicators help illustrate how well an organization is doing in meeting its objectives or achieving the desired outcomes. They are a means of assessing and evaluating the characteristics of products, services, processes and operations of the organization. They need to be relevant to the program's desired outcomes and objectives, quantifiable, verifiable and free from bias.

- Key performance indicators are quantifiable measurements, agreed to beforehand, that reflect the critical success factors of an organization. Whatever key performance indicators are selected, they must reflect the organization's goals, they must be key to its success, and they must be quantifiable (measurable). Key performance indicators usually are long-term considerations.

- Standards (or targets) are norms or timeframes or sometimes just directions (such as "increase" or "improve" some measured situation) that enable an organization to use performance indicators to "judge" performance.

The OECD has concluded ${ }^{3}$ that a performance management strategy is a positive element in any modernization program. Countries that have performance measurement in place are said to have seen improvement in management reforms, efficiency, cost awareness and effectiveness. Clarity and transparency surrounding accountability at the political and administrative levels of government also improves. Countries are moving increasingly to correcting and adjusting their systems and to increase the use of performance measurement in areas such as budget formulation and tax administration.

\section{How Do Tax Administrations Apply Performance Management at the Strategic Level?}

Performance within any organization can broadly be measured at three separate levels:

- at the strategic level, where the overall "health" of the organization can be evaluated across a series of key indicators, such as financial performance, customer satisfaction, management and staff competencies, integrity, etc.

- at the operational level, where efficiency of output production is the focus of measurement;

- at the individual staff member level, where personal performance can be measured against pre-determined standards and objectives.

- This is illustrated in Figure 1 below.

\footnotetext{
${ }^{3}$ In Search of Results: Performance Management Practices. Organization for Economic Cooperation and Development. 1997.
} 
Figure 1. Levels of performance measurement

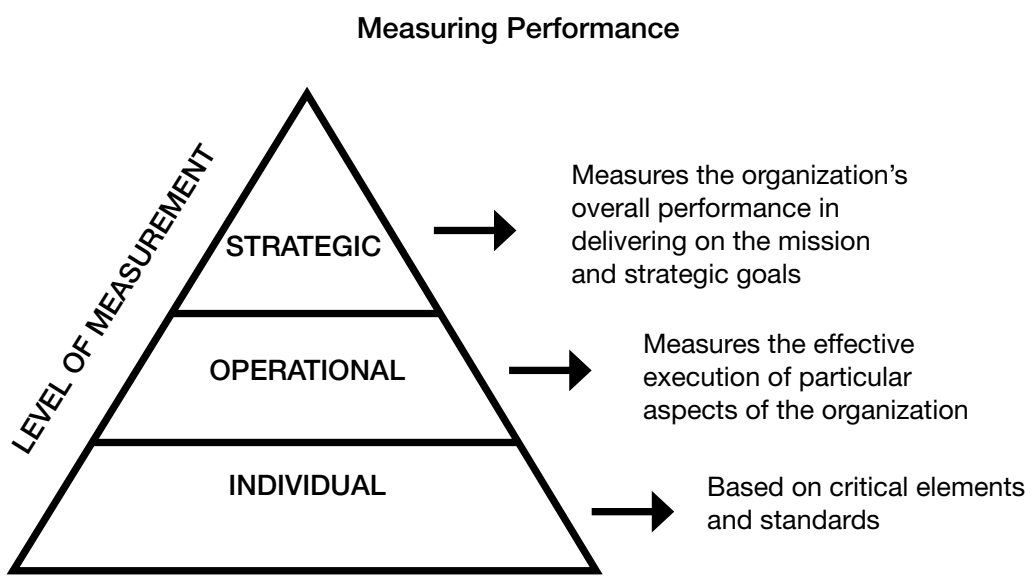

In many tax administrations, performance is measured at all three levels and there are clear linkages among them. For example, performance indicators for managers need to be consistent with and tied to performance targets at the operational level, and operational outputs should support the overall strategic direction for the organization.

At the strategic level, goals should be kept to a relatively small number so as to ensure the tax administration can focus on the most important and achievable priorities. Some tax administrations will articulate only a few high level strategic goals (from 3 to 6), most often clustered around themes such as: improved compliance; a customer centered focus; organizational renewal; staff engagement; increased productivity; cost effectiveness; and return on investment.

The high level goals are focused on high-level outcomes (or impacts) and tend to have a small number of qualitative measures or indicators aimed at assessing how effective the organization has been in achieving those outcomes. No single indicator will provide sufficient information to assess the extent to which the organization has been successful, so a set of complementary indicators is necessary.

At this level, specific measures will:

- apply to the whole organization

- cut across functional lines

- tend to reflect very high-level outcomes

- support the strategic goals and the highest level objectives

Box 1 shows examples of typical goals and related performance measures at the strategic level. 


\section{Box 1. Typical goals and performance measures at the strategic level}

Typical strategic goals

- improve compliance with the tax laws

- develop a customer centered focus

- foster organizational renewal and an efficient, ethical and adaptive organization

- increase productivity and cost effectiveness

- ensure taxpayers meet their obligations

- maintain community confidence

- improve ease of compliance

- ensure revenue is available to fund government programs through people meeting payment obligations of their own accord

- ensure people receive payments they are entitled to, enabling them to participate in society
- create an environment which promotes compliance

- continually invest in people and technology to deliver future outcomes

Typical performance measures

- Total net revenue collected by tax type compared to forecast

- Total expenditures compared to approved budget

- Ratio of costs to collections (direction)

- Filing and payment compliance rates (direction)

- Income reporting compliance (from audit)

- Taxpayer satisfaction surveys

\section{How Do Tax Administrations Apply Performance Management at the Operational Level?}

Each of the goals referred to in the previous section is in turn broken down into a limited set of more specific operational objectives which outline in more detail what will need to be achieved in order to realize the outcome expressed in the goal. Activities (or initiatives) are specific tasks (such as increasing electronic filing or expanding audit coverage rates). Each objective is usually supported by several activities, which collectively represent the strategy for achieving the objective.

As part of the strategy, the tax administration needs to develop a comprehensive set of operational performance measures that provides a focus on activities within each key functional area of the tax administration. The selected measures, as much as possible, must:

- embody characteristics of quantity, quality, and timeliness

- be measurable - a performance standard that cannot be measured has no purpose and is likely to detract from the credibility of any performance measurement initiative.

- be verifiable - the reported results for any performance measure must be open to scrutiny to ensure any misreporting of results can be detected and corrected. 
Table 1. Illustrative Performance Indicators for tax administration

\begin{tabular}{|c|c|c|}
\hline $\begin{array}{l}\text { Tax administration } \\
\text { functions }\end{array}$ & Quantity measures & $\begin{array}{l}\text { Timeliness and quality mea- } \\
\text { sures }\end{array}$ \\
\hline $\begin{array}{l}\text { Registration and } \\
\text { filing compliance }\end{array}$ & $\begin{array}{l}\text { Number of new registrants } \\
\text { Number of non-filers by tax type }\end{array}$ & $\begin{array}{l}\text { Average time to complete new } \\
\text { registration } \\
\text { Average time to resolve non- } \\
\text { filer case } \\
\text { Late penalties assessed } \\
\text { Accuracy of taxpayer register }\end{array}$ \\
\hline $\begin{array}{l}\text { Taxpayer services } \\
\text { and education }\end{array}$ & $\begin{array}{l}\text { Total Number of taxpayers assisted } \\
\text { - Telephone } \\
\text { - Walk-in } \\
\text { Written correspondence } \\
\text { - E-mail } \\
\text { - Internet site hits } \\
\text { Number of advisory visits } \\
\text { Number of educational seminars }\end{array}$ & $\begin{array}{l}\text { Average taxpayer wait time for } \\
\text { service } \\
\text { Average time to respond to writ- } \\
\text { ten taxpayer requests } \\
\text { Accuracy of responses provided } \\
\text { Utility of visits and seminars (de- } \\
\text { termined by surveys) }\end{array}$ \\
\hline $\begin{array}{l}\text { Returns processing } \\
\text { and payment }\end{array}$ & $\begin{array}{l}\text { Number of returns processed, by tax type } \\
\text { Number of refunds issued, by tax type } \\
\text { Percentage of returns filed electronically } \\
\text { Percentage of returns filed by paper } \\
\text { Number of payments processed (manually } \\
\text { and electronic) } \\
\text { Total value of payments processed }\end{array}$ & $\begin{array}{l}\text { Average processing time } \\
\text { Average number of days to } \\
\text { issue a refund } \\
\text { Return processing accuracy/ } \\
\text { error rate } \\
\text { Payment processing accuracy/ } \\
\text { error rate }\end{array}$ \\
\hline Arrears collection & $\begin{array}{l}\text { Total value of arrears collected } \\
\text { Total number of collection cases closed } \\
\text { Total number of taxpayers contacted } \\
\text { Total resources (person years) assigned } \\
\text { Average annual collection per person year }\end{array}$ & $\begin{array}{l}\text { Average age of collection cases } \\
\text { Percentage of cases resolved } \\
\text { within X months } \\
\text { Collection case quality (based on } \\
\text { specific scoring tools) }\end{array}$ \\
\hline Audit and investigations & $\begin{array}{l}\text { Number of audits completed by tax type (and } \\
\text { by taxpayer segment where applicable) } \\
\text { - Simple } \\
\text { - Comprehensive } \\
\text { - Thematic } \\
\text { - Etc. } \\
\text { Additional tax assessed by audit, by tax type } \\
\text { Total resources (person years) assigned } \\
\text { Additional tax assessed per person year } \\
\text { Number of investigations completed }\end{array}$ & $\begin{array}{l}\text { Average time to complete audit } \\
\text { by type of audit } \\
\text { Audit quality (based on specific } \\
\text { scoring tools) } \\
\text { Average time to complete an } \\
\text { investigation }\end{array}$ \\
\hline Appeals & $\begin{array}{l}\text { Total number of appeals cases closed } \\
\text { Total resources (person years) assigned } \\
\text { Value of adjustments on appeal } \\
\text { Number of cases heard by courts }\end{array}$ & $\begin{array}{l}\text { Average length of appeals case } \\
\text { Appeals case quality (based on } \\
\text { specific scoring tools) } \\
\text { Degree to which legal deadlines } \\
\text { are met }\end{array}$ \\
\hline
\end{tabular}

Measures can be primarily qualitative or primarily quantitative. Quantitative measures can include the number of actions taken by the tax administration (e.g., number of audits conducted, number of taxpayers served, number of returns processed) and the degree of 
efficiency with which the actions are carried out (number of calls answered per tax officer, number of collection cases closed per tax bailiff, the average amount of taxes assessed per hour of auditor time).

Qualitative measures assess the extent to which the taxpayer services and enforcement actions delivered by the tax agency meet established standards. They are determined by comparing a sample of work items carried out by tax officers against a prescribed set of standards.

The tax administration must establish baseline levels of performance against which future standards can be established. When new measures are first created it is necessary to establish a baseline level of performance. Once the baseline is determined, then targets can be set for future performance. These targets are norms or timeframes or sometimes just directions (such as "increase" or "improve" some measured situation) that enable an organization to use performance indicators to "judge" performance.

Examples of typical tax administration performance measures including quantity, quality and timeliness are found Table 1.

\section{How Do Tax Administrations Apply Performance Management at the Individual Staff Member Level?}

Overall arrangements for performance management in an organization are often referred to as the Performance Management Framework. A fundamental component of any Performance Management Framework is the ability to measure performance at both the organizational and individual level.

Best practice in tax administration suggests that assessment of individual performance needs to be cast in the context of organizational performance. The idea is for individual performance agreements to be logically linked with organizational performance. This approach helps achieve 'line of sight' between the organization's outcomes and individual performance measures and supports measurement of the individual's contribution to organizational outputs.

Performance measures used in individual performance agreements often contribute directly to remuneration outcomes for that individual. The credibility of the overall performance management system and pay outcomes will therefore be linked directly to the perceived appropriateness and fairness of the performance measures.

An important concept in the development of performance indicators for individuals is the cascading of the performance indicators of the organization. Depending on the specific position of the individual concerned, a broad organizational goal such as "improve compliance with the tax laws" could cascade down to "increase comprehensive audit coverage for VAT for large taxpayers" for the Head of the Large Taxpayer Office or its Chief of Audit. 
In summary,

- Staff performance must be aligned to the strategic objectives of the organization

- Individual performance objectives must be timely, consistent, and transparent

- Performance indicators in operational plans must translate into individual accountability

- Individual performance objectives must roll up to unit plans, which in turn are aligned to divisional plans, and so on.

\section{What Are Some of the Key Tasks In Implementing a Performance Management System?}

Some tax administrations have introduced comprehensive performance management systems but many have not. Without such a system, the achievement of organizational goals and objectives will be jeopardized and the accountability and transparency of an effective tax administration will be lacking.

There are some essential tasks in implementing a performance management system (or framework):

- Identify the key performance measures - the tax administration needs to identify a set of quantitative and qualitative measures for each function. Which measures are selected will depend on the strategic and operational priorities that have been established.

- Specify the details of each performance measure -in order to ensure the validity and reliability of each performance measure, require a detailed definition of each measure, the methodology for calculating the measure, the data source(s), the frequency of reporting, and a description of the steps taken to record or process the measurement data.

- Establish baseline levels against which future standards can be set-when new measures are first created it is necessary to establish a baseline level of performance. Once the baseline is determined, then targets or goals can be set for future performance. Sometimes the quantitative aspect of a measure is simply a "direction" from a given baseline (improve or increase, for example).

- Analyze and report results for each measure-once a set of tax administration results measures is in place, reports should regularly be prepared. These reports should be provided to all managers and employees directly involved in the measure, and should provide results overall and results by location. The information provided for each measure should include the target, actual performance to date, and past results if available. An analysis of performance against target should be conducted for each measure.

- Ensure quality of work performed-for tax administration, quality is often synonymous with accuracy. Assessments of the extent to which the correct or 
appropriate procedures were followed can be determined through a review of a sample of work products or services produced by each function. Optimally, a quality review should be conducted annually on a statistically valid sample of the work products completed by a function over the course of a year, provided such products have quality standards.

- Determine organizational responsibility for the performance management framework - the tax administration needs to assign specific responsibility for development and maintenance of its performance measurement framework. This could be within the strategic and operational planning area or in some other area (such as finance and administration or corporate services), it could be a dedicated unit or combined with other related functions. These decisions often depend on the size of the tax administration. In any event, the responsible unit will have to: provide guidance and direction; establish a consistent framework, format and standards; determine systems and data sources; and review overall results and identify areas of good performance and best practices and areas of weakness.

\section{What Has Been the Experience with Performance Management in Different Countries?}

Tax administration experience with performance management has been quite diverse. In many OECD and other countries performance management is very well advanced and assuming greater importance. In other countries, especially developing economies, performance management is just getting underway. This section illustrates two separate and unrelated examples: Romania (Box 2), which tried and failed but which is trying again to implement performance measurement; and Canada (Box 3), which has been measuring and tracking performance for many years.

\section{Key Points for Tax Administration Design}

- Performance measurement is increasingly important in public administration.

- In tax administration, the management of performance needs to be linked to both strategic and operational planning.

- Individual performance must also be tied to organizational performance measurement.

- Performance indicators need to have quantity, quality and timeliness characteristics.

- Key tasks for a tax administration include: identifying key measures of performance and specifying all related details; setting a baseline against which future performance can be assessed; analyzing and reporting results; and establishing organizational responsibility for the performance management framework. 


\section{Box 2. Romania}

Romania is a country with a population of some 23 million, and a national agency for fiscal administration (tax and customs) decentralized across 42 provinces (judets) with a network of about 300 offices. Performance indicators were established for 2004 and 2005 in consultation with the regional offices. Data was collected at the local level. A total of 12 indicators was developed, including for each the name of the indicator, the goal to be achieved, the method of computing the indicator (scope and formula), and the reporting frequency. These indicators were:

- \% of letters answered within 20 days

- Level of voluntary compliance for returns filing

- Level of voluntary compliance for payment

- Enforced collection amounts from large taxpayers

- Revenue collected versus revenue expected

- \% revenue collected through enforced collections

- Average annual audits per tax auditor

- Additional amounts assessed from audit

- Additional amounts assessed from audit per auditor

- \% of tax assessments appealed

- \% of appeals in favor of taxpayer

- \% of appeals in favor of the tax administration.

By any standard, these measures constituted a reasonable start, and the necessary data were available. However, there were deficiencies in the approach and in the measures themselves that resulted in a failed experiment and the measures were effectively abandoned. There were many reasons for this, but the main ones were:

- The data were produced, but management did not pay attention to them. There were no consequences associated with changes (good or bad) in the performance indicators. Eventually, system fell in to disuse.

- Few indicators had standards or targets. As a result it was very difficult to judge whether progress was being made.

- Some indicators were largely out of the control of the tax administration. For example, the disposition of appeals.

- There were no prior agreements on what changes in the indicators might mean. For example, did an increase in additional tax assessed by audit represent more efficient audit or a decrease in compliance, or both?

In 2007 the draft strategic plan of the tax administration introduced in a more systematic manner a number of performance measures for the organization. In fact, it goes much beyond the previous 12 indicators and includes almost all areas of the organization. All indicators were based on and were relevant to the strategic plan of the organization. Management performance review was linked to success against indicators.

Furthermore, as a follow-up to the strategic plan, the new strategic planning unit has begun a comprehensive development of performance indicators at the local, regional and national level. 


\section{Box 3. Canada}

In Canada, tax administration is carried out by the Canada Revenue Agency (CRA). This organization has some 40,000 employees, 40 tax service offices and 7 large processing centers. The CRA has been in the business of managing performance for many years but still recognizes it has improvements that can be made: it's 2008/09 Annual Report to Parliament states "We use qualitative and quantitative indicators to determine the results achieved in terms of our strategic outcomes and expected results. Survey results, statistical sampling, and operational data inform our assessments. Although we have made progress in developing robust indicators for each of our strategic outcome measures and expected results, we need to make some of them more concrete and measurable".

Canada sets out just two strategic outcomes:

- Taxpayers meet their obligations and Canada's revenue base is protected.

- Eligible families and individuals receive timely and correct benefit payments.

Strategic results and program activities are rated in terms of whether the targets identified in the Corporate Business Plan were met, mostly met, or not met. The targets identify the percentage or degree the CRA expects to attain for a performance level. Performance targets are established by management teams through analysis of affordability constraints, historical performance, the complexity of the work involved, and the expectations of Canadians.

To assess performance against its first strategic outcome, the CRA uses just 4 measures (some of which have more than one indicator) as set out below:

Registration Compliance-estimates the proportion of Canadian businesses that have registered as required by law to collect the GST/HST.

\begin{tabular}{|c|c|c|c|c|c|c|}
\hline \multicolumn{1}{|c|}{ Indicator } & $\begin{array}{c}\text { Current } \\
\text { Target }\end{array}$ & 2005-2006 & 2006-2007 & 2007-2008 & 2008-2009 & Rating \\
\hline $\begin{array}{l}\text { Canadian businesses } \\
\text { that were registered } \\
\text { for the GST/HST }\end{array}$ & $90 \%$ & $96.8 \%$ & $97.7 \%$ & $97.0 \%$ & $93.8 \%$ & Met \\
\hline
\end{tabular}

Filing Compliance-indicators estimate the proportion of the Canadian population who file their returns on time.

\begin{tabular}{|l|c|c|c|c|c|c|}
\hline \multicolumn{1}{|c|}{ Indicators } & $\begin{array}{c}\text { Current } \\
\text { Target }\end{array}$ & 2005-2006 & 2006-2007 & 2007-2008 & 2008-2009 & Rating \\
\hline $\begin{array}{l}\text { Income tax filing rate } \\
\text { for individuals }\end{array}$ & $90 \%$ & $92.8 \%$ & $93.0 \%$ & $92.5 \%$ & $92.8 \%$ & Met \\
\hline $\begin{array}{l}\text { Corporations - Tax- } \\
\text { able incorporated } \\
\text { businesses that filed } \\
\text { their returns on time }\end{array}$ & $90 \%$ & $86.4 \%$ & $86.4 \%$ & $85.8 \%$ & $84.4 \%$ & Not Met \\
\hline $\begin{array}{l}\text { Businesses that filed } \\
\text { their GST/HST returns } \\
\text { on time }\end{array}$ & $90 \%$ & $91.8 \%$ & $91.4 \%$ & $\mathrm{n} / \mathrm{a}$ & $90.5 \%$ & Met \\
\hline $\begin{array}{l}\text { Employers who filed } \\
\text { their returns on time }\end{array}$ & $90 \%$ & $94.5 \%$ & $96.0 \%$ & $95.5 \%$ & $96.4 \%$ & Met \\
\hline
\end{tabular}




\section{Box 3. Canada (concluded)}

Reporting Compliance-indicators contribute to the assessment of the degree to which taxpayers report complete and accurate information.

\begin{tabular}{|l|c|c|c|c|c|c|}
\hline \multicolumn{1}{|c|}{ Indicators } & $\begin{array}{c}\text { Current } \\
\text { Target }\end{array}$ & 2005-2006 & 2006-2007 & 2007-2008 & 2008-2009 & Rating \\
\hline \multicolumn{7}{|c|}{ Non-compliance Rate Estimates } \\
\hline $\begin{array}{l}\text { Key tax credits } \\
\text { and deductions } \\
\text { not subject } \\
\text { to third-party } \\
\text { reporting-Indi- } \\
\text { viduals }\end{array}$ & $\begin{array}{c}\text { Downward } \\
\text { trend }\end{array}$ & $15.5 \%$ & $14.7 \%$ & $14.8 \%$ & $16.5 \%$ & Not Met \\
\hline $\begin{array}{l}\text { Random } \\
\text { audits-Small } \\
\text { and Medium- } \\
\text { sized Corporate } \\
\text { filers }\end{array}$ & N/A & N/A & N/A & N/A & $13.8 \%$ & N/A \\
\hline
\end{tabular}

Remittance Compliance-indicators estimate the proportion of taxpayers who owed taxes and paid the full amount on time.

\begin{tabular}{|l|c|c|c|c|c|c|}
\hline \multicolumn{1}{|c|}{ Indicators } & $\begin{array}{c}\text { Current } \\
\text { Target }\end{array}$ & 2005-2006 & 2006-2007 & 2007-2008 & 2008-2009 & Rating \\
\hline $\begin{array}{l}\text { Individuals } \\
\text { who paid their } \\
\text { reported taxes } \\
\text { on time }\end{array}$ & $90 \%$ & $92.4 \%$ & $92.9 \%$ & $91.5 \%$ & $93.2 \%$ & Met \\
\hline $\begin{array}{l}\text { \% of corpora- } \\
\text { tions that paid } \\
\text { reported taxes } \\
\text { on time }\end{array}$ & $90 \%$ & $92.9 \%$ & $90.9 \%$ & $92.4 \%$ & $92.2 \%$ & Met \\
\hline $\begin{array}{l}\text { Businesses that } \\
\text { collected GST/ } \\
\text { HST }\end{array}$ & N/A & $2.8 \mathrm{M}$ & $3.0 \mathrm{M}$ & $3.0 \mathrm{M}$ & $3.3 \mathrm{M}$ & N/A \\
\hline $\begin{array}{l}\text { Employers } \\
\text { paying source } \\
\text { deductions on } \\
\text { time }\end{array}$ & $90 \%$ & $88.7 \%$ & $87.7 \%$ & $89.2 \%$ & $87.3 \%$ & Mostly \\
\hline $\begin{array}{l}\text { Trend in ratio of } \\
\text { outstanding tax } \\
\text { debt to gross } \\
\text { cash receipts }\end{array}$ & $\begin{array}{l}\text { Downward } \\
\text { trend }\end{array}$ & $5.62 \%$ & $5.79 \%$ & $6.23 \%$ & $6.64 \%$ & Not Met \\
\hline
\end{tabular}

Where targets are not met, strategies to redress the situation are set out in the next strategic and operational plans. 


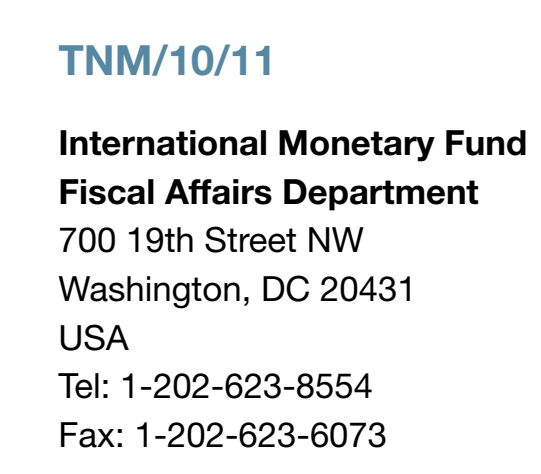

